\title{
Higher education as a sustainable development tool
}

\author{
Elena Molokova*
}

Ural State University of Economics, 8 Marta str./Narodnaya Volya, 62/45, 620144 Yekaterinburg, Russia

\begin{abstract}
The article is devoted to the assessment of the role of higher education in ensuring socio-economic sustainability of society development. Based on the analysis of international and Russian legal acts, it identifies the main indicators that allow analyzing the impact of higher education system on the implementation of sustainable development goals. Particular attention is paid to assessment of accessibility of education. Based on the analysis of statistical data, it is concluded that there is a problem of differentiation of regions and territories in terms of access to higher education due to uneven location of educational institutions, different density of students, low interregional mobility of population and disproportions in incomes of the population. Regional differentiation in access to higher education in Russia leads to a number of socio-economic problems that reduce the sustainability of regional development, including the outflow of young people and uncompensated labour migration.
\end{abstract}

\section{Introduction}

The world is currently engaged in an intense search for a better model for higher education that can provide contemporary strategies for moving towards sustainable development. Higher education, as the most important social and economic institution of society, has significant potential to become the core of humanity's quest for harmonising social relations, combining social justice, environmental security and economic efficiency.

Building on the components of sustainable development (economic, social and environmental) as enshrined in UN General Assembly Resolution N 70/1 of 25 September 2015 on the 2030 Agenda for Sustainable Development, as well as the Agenda, which includes 17 goals (SDGs) and global indicators, we note that higher education can be fully positioned as a means to achieve sustainable development. In particular, Goal 4 «Ensure inclusive and equitable quality education and promote lifelong learning opportunities for all», as well as Goals 8 and 9, can be realised through the development of higher education. Indirectly, the impact of higher education supports the implementation of the entire Sustainable Development Agenda [1].

At the same time, according to most academic sources, the problem area of sustainable development consists of economic efficiency, social justice and environmental security.

\footnotetext{
* Corresponding author: elmo.sm@mail.ru
} 
The positioning of the higher education system as a means of achieving the UN Sustainable Development Goals [2] makes it appropriate to consider it in the context of the Shared Value Framework, which integrates the potential of the market economy, the social interests of society and governmental regulatory influence.

Thus, the context described above requires the study of the higher education system in an interdisciplinary field (economics, sociology, ecology, law) in market-state coordinates, viewing it as an integrated public relation between the state, society and business.

The methodological prerequisites of the study are a set of scientific approaches to the interpretation of the concept of «sustainable development», providing cognitive potential to study the role of higher education in the implementation of sustainable development goals [3].

At present, it is possible, with a certain degree of conditionality, to distinguish, due to the diversity and mobility of the analyzed field of study: (1) socio-ecological theories, (2) catastrophe theory, (3) transformation theory, (4) concept of corporate sustainability, (5) concept of shared values, (6) sustainable development as the basis of modern socialism, (7) theory of expanded reproduction of capital: human, economic, natural and others [4], spatial approach to measure sustainable development goals [5].

Using the epistemological possibilities of the spatial approach, let us describe one of the indicators of higher education effectiveness in achieving global sustainability of humanity under the fourth goal «ensuring inclusive and equitable quality education and encouraging lifelong learning opportunities for all», namely, equal accessibility of higher education.

\section{Materials and methods for analyzing the role of higher education in sustainable development}

Based on a retrospective analysis of the United Nations documents on sustainable development, three notional stages can be identified in the evolution of approaches to understanding and ensuring human development. The first stage can be dated back to 1972 with the adoption of the UN Stockholm Declaration on the Environment, which initiated discussions and teachings on the need for biocompatibility between humans and nature, and the impossibility of societal development outside the framework of environmental requirements. This period ended by the early $1990 \mathrm{~s}$ with the formation of the idea of the need for a transition to sustainable development according to the formula: «development that meets the needs of the present without compromising the ability of future generations to meet their own needs» [6]. This period for the Russian higher education system was marked by the beginning of the growth of demand, the increase in the scale of activities, the number of educational institutions and students in them. Courses and programs devoted to ecology appeared in the universities.

The beginning of the next phase of development of the concept can be dated back to 1992 with decisions of UN conferences in Rio de Janeiro, including «Agenda 21», where the role of the social factor in sustainable development was reconsidered. The second stage was characterized by unprecedented growth of the Russian education system and intensive search for an effective model combining state and market regulation. There has been a slow but progressive development of environmental education in the country.

The contours of the third, modern stage of development of the concept were outlined by the influence of the financial and economic crisis of 2008-2009, which finally convinced the world community that the efficiency of the current economic model determines the progressive development of mankind. The document "Sustainable Development Goals" adopted at the New York conference in 2015 is the most formalized act in the process of humanity's sustainable development. The beginning of this stage coincided with the processes of commercialisation of the higher education system in Russia and the fall in 
demand for environmental specialties in the face of the demand for "commercial" fields (law, economics, management).

It should be noted that the formation and development of the doctrine of sustainable development and the role of higher education in it is conditioned and inextricably linked to the understanding of the above-mentioned historical context.

The World Declaration on Higher Education for the 21st Century: Vision and Action, 9 October 1998, states that without adequate higher education and research facilities producing an adequate pool of qualified and educated individuals, sustainable development cannot be achieved. In doing so, the task of education, training and research is identified as one that contributes to sustainable development. Thus, indicators of the role of higher education in sustainable development are: (1) training of highly qualified personnel, (2) lifelong learning opportunities, (3) development of scientific research [7], (4) preservation of cultural pluralism and diversity, (5) preservation and promotion of shared values.

The Roadmap for Implementation of the Global Action Programme on Education for Sustainable Development identifies key development areas among the priorities, with a focus on developing «green» programmes and promoting the principles of sustainable development [8].

In order to analyse the potential contribution of the Russian higher education system to the implementation of the Sustainable Development Goals, the above-mentioned areas (indicators) should be used as a benchmark, but the Russian Federation has not developed its own methodology for assessing the SDG indicators. The data provided by the Federal State Statistics Service are the minimum possible set of indicators that do not illustrate the full picture of the importance of higher education for sustainable development. Currently, official statistics in the context of assessing the implementation of the fourth Sustainable Development Goal in the Russian Federation presents data on five indicators, three of which are directly related to higher education: the share of adults and youth with skills in information and communication technologies and the gross enrolment ratio in higher education programs - Bachelor, Specialist, Master, as a percentage of the population aged 17-25 years (Figure 1). Thus, it reports solely on the indicators proposed by the UN in «Towards 2030: A New Vision for Education».

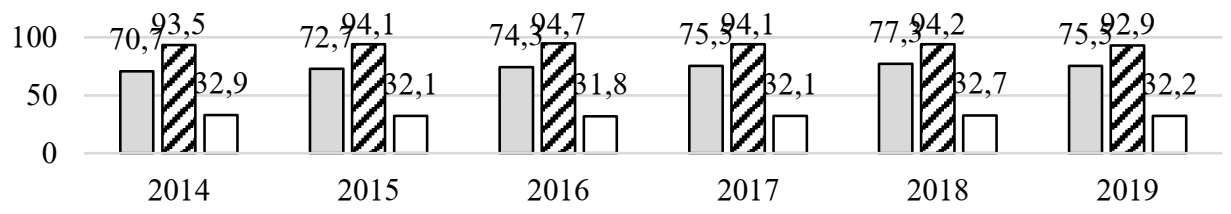

$\square$ Proportion of adults with information and communications technology skills as a percentage of the total population aged 15-74

a Proportion of adults with information and communications technology skills as a percentage of the total population aged 15-74

$\square$ Gross enrolment ratio in higher education - bachelor's, specialist and master's degree programmes, as a percentage of the population aged 17-25

Fig. 1. Data from the Federal State Statistics Service demonstrating the implementation of Sustainable Development Goal 4 [9].

The analysis of the data in Figure 1 illustrates the negative dynamics of all indicators by 2019. Positioning higher education as a universal indicator of sustainable development, let us characterize its indicators that are not attributed by the Federal State Statistics Service to the indicators of the fourth goal "Ensuring inclusive and equitable quality education and promoting lifelong learning opportunities for all". 
Based on the UN sustainable development ideology and the objectives, indicators, indicators of higher education system development listed in the adopted documents, we will highlight three conditional areas, the assessment of which will make it possible to conclude on the effectiveness of the higher education system in the implementation of Goal 4: (1) accessibility of higher education, (2) possibility of lifelong learning, (3) implementation of public goals (preservation of cultural diversity, strengthening of public values, etc.), (4) quality of education and (5) inclusion of sustainable development principles, environmental disciplines and directions in educational programs.

Let us demonstrate this in the context of the one area we have identified: accessibility of education. Based on the available statistical data, it is necessary to assess: (1) the number of educational institutions of higher education and students in them, (2) the territorial development of the higher education system, illustrating the possibility of obtaining it for the residents of Russian regions. At the same time, this article does not consider the financing of higher education, which significantly affects the accessibility of education, as well as the inclusive range of indicators that provide enhanced educational opportunities for people with disabilities.

It should be noted that due to different interpretations of sustainable development goals in science and practice in different countries, and the lack of a generally accepted evaluation methodology, the indicators below can be interpreted differently, moreover, most of them can only indirectly characterize the processes under analysis. However, it seems that the combination of these indicators provides an indication of the vector of higher education development in the context of the implementation of the Sustainable Development Goals.

The analysis of accessibility of higher education should focus on the regional aspect of this indicator. In particular, let us assess the territorial location of higher education institutions (table 1).

Table 1. Number of independent higher education institutions and branches per capita by Federal District of the Russian Federation [10].

\begin{tabular}{|l|l|l|l|l|l|}
\hline Federal District & $\begin{array}{l}\text { Number } \\
\text { of } \\
\text { independe } \\
\text { nt } \\
\text { education } \\
\text { al } \\
\text { institution } \\
\text { s }\end{array}$ & $\begin{array}{l}\text { Number } \\
\text { of } \\
\text { branches } \\
\text { of } \\
\text { independe } \\
\text { nt } \\
\text { organisati } \\
\text { ons }\end{array}$ & $\begin{array}{l}\text { Total } \\
\text { number of } \\
\text { HEIs }\end{array}$ & $\begin{array}{l}\text { Populatio } \\
\text { n size }\end{array}$ & $\begin{array}{l}\text { Number } \\
\text { of } \\
\text { universiti } \\
\text { es per } \\
\text { person }\end{array}$ \\
\hline Russian Federation & 710 & 549 & 1259 & 14676465 & 0,000835 \\
\hline Central Fereral District & 258 & 128 & 386 & 39405807 & 0,00097 \\
\hline North-West Federal District & 87 & 42 & 129 & 13977031 & 0,00092 \\
\hline South Federal District & 58 & 83 & 141 & 16460317 & 0,00085 \\
\hline $\begin{array}{l}\text { North Caucasian Federal } \\
\text { District }\end{array}$ & 40 & 40 & 80 & 9898841 & 0,0008 \\
\hline Volga Federal District & 111 & 125 & 236 & 29342448 & 0,0008 \\
\hline Ural Federal District & 47 & 47 & 94 & 12355437 & 0,00076 \\
\hline Siberian Federal District & 70 & 50 & 120 & 17145861 & 0,00069 \\
\hline Far Eastern Federal District & 39 & 34 & 73 & 8178913 & 0,00089 \\
\hline
\end{tabular}

These tables show the presence of regional differentiation in the location of higher education institutions, which indicates unequal access to them for the population, in particular, the lowest coefficient is observed in the Ural Federal District. This trend is also observed in the location of higher education institutions and the number of students by constituent regions of the Russian Federation (Figures 2 and 3). Moscow is the leader in terms 
of the number of higher education institutions; the Republic of Dagestan completes the top ten regions with the largest number of higher education institutions (figure 2).

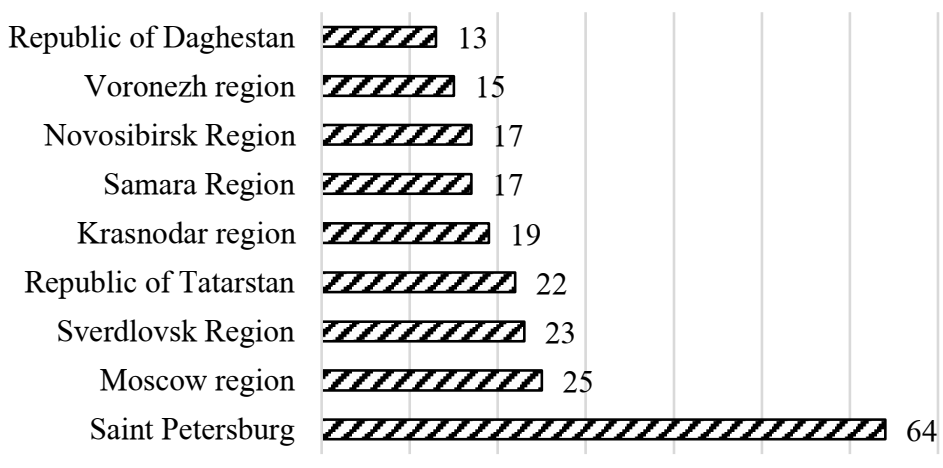

๑Number of HEIs

$\begin{array}{llllllll}0 & 10 & 20 & 30 & 40 & 50 & 60 & 70\end{array}$

Fig. 2. Top 10 regions by the number of higher education institutions [10].

Clearly, the uneven spatial distribution of educational institutions has a cumulative effect:

Firstly, for households with low incomes, it may not be feasible to finance a child's travels to and from school and assistance in living in another region;

Secondly, the low inter-regional mobility of the Russian population creates uncertainty about the possibility of moving to another region of the country for education;

Thirdly, currently in Russia, despite the introduction of the United State Exam, which has significantly increased the chances of entering any higher education institution in the country, regardless of the region, there is still a difference in the level of school education and effectiveness of preparation for the unified state examination, which also reduces the level of accessibility of higher education.

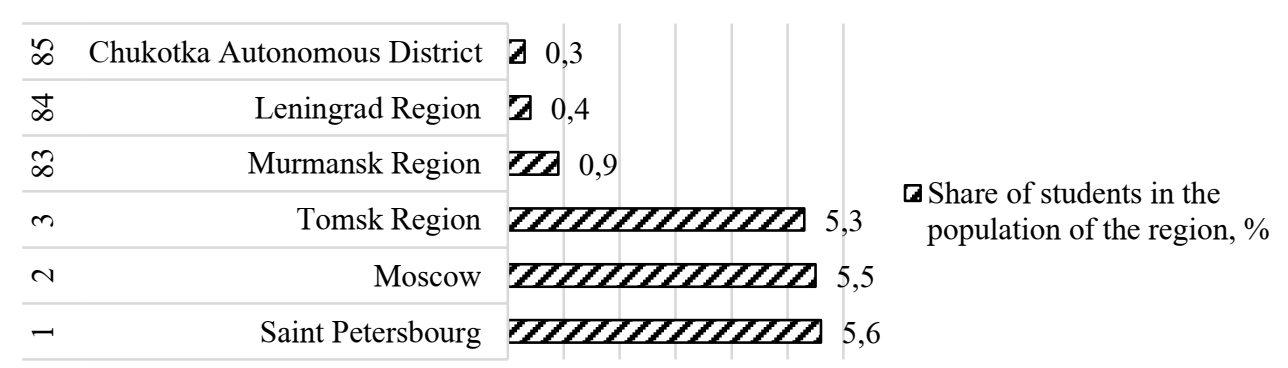

$\begin{array}{lllllll}0 & 1 & 2 & 3 & 4 & 5 & 6\end{array}$

Fig. 3. Regions with the highest and lowest density of students per capita, \% [10].

More than ten universities are located in only 15 regions of Russia, with only one or two educational institutions of higher education located in 20 regions of the country and $28.8 \%$ of all universities are located in Moscow and St. Petersburg. More than half of all Russian students study in 12 regions of Russia (Table 2). 
Table 2. Top regions by the number of higher education students studying in them [10].

\begin{tabular}{|l|l|l||l|l|c|}
\hline $\begin{array}{l}\text { Positio } \\
\mathrm{n}\end{array}$ & Region & $\begin{array}{l}\text { Number } \\
\text { of } \\
\text { students, } \\
\text { people }\end{array}$ & Position & Region & $\begin{array}{l}\text { Number } \\
\text { of } \\
\text { students, } \\
\text { people }\end{array}$ \\
\hline 1 & Moscow & 699843 & 7 & $\begin{array}{l}\text { Republic of } \\
\text { Bashkortostan }\end{array}$ & 97187 \\
\hline 2 & Saint-Petersbourg & 302616 & 8 & Novosibirsk Region & 96319 \\
\hline 3 & Republic of Tatarstan & 143941 & 9 & Samara Region & 94568 \\
\hline 4 & Rostov region & 133154 & 10 & Chelyabinsk Region & 88844 \\
\hline 5 & Sverdlovsk Region & 119384 & 11 & Voronezh region & 85071 \\
\hline 6 & Krasnodar region & 109182 & 12 & Nizhny Novgorod region & 83490 \\
\hline
\end{tabular}

Thus, equal accessibility of higher education is reduced by uneven spatial distribution of educational institutions.

Moreover, regions with a more developed higher education system have traditionally been an attraction for the labour force as well, which provokes not just an outflow of young people from the region to study, but also subsequent employment in major Russian cities, creating a shortage of qualified personnel in the territories. Another problem in the context of the current situation is the outflow of the strongest applicants to the cities of attraction, which causes a gradual weakening of regional education systems, a decrease in the level of applicants and, as a consequence, their ability to successfully master educational programmes.

Thus, the existing regional differentiation in the availability of higher education in Russia provokes a set of socio-economic problems that reduce the sustainability of territorial development.

This situation has been exacerbated by the recent reduction in the number of HEIs, as part of the implementation of state policy based on the results of performance monitoring in 20142017. The result was a $31.5 \%$ reduction in the number of non-state universities and an $18.3 \%$ reduction in the number of state-funded universities, resulting in an $18 \%$ and $19 \%$ reduction in the number of students, respectively.

It seems that the past reduction clearly did not take into account the possibility of developing problems related to regional differentiation and interregional uncompensated migration.

\section{Results and discussion of the impact of the territorial factor of the higher education system on sustainable development}

Russia is now systematically adopting strategic documents aimed at ensuring the global competitiveness of national higher education. The National Project «Education» is being implemented. The analysis of its content allows noting the lack of coherence and correlation of sustainable development goals and objectives set by the state in this document. In the framework of the expert-analytical event conducted by the Accounts Chamber of the Russian Federation to assess the integration of the Sustainable Development Agenda in the national context, it is noted that the national development goals are largely reflected in the strategic documents, but the largest share of indicators that require additional coordination at this stage refers to the fourth goal «Ensuring inclusive and equitable quality education and promoting lifelong learning opportunities for all» - (64\%) [11]. Moreover, there is currently no formalized obligation of the bodies that develop strategic documents to ensure the interrelation of the sustainable development goals and sectoral development objectives and directions. 
As shown above, Russia lacks a monitoring system that allows the fullest and most comprehensive reflection of the effectiveness of the implementation of sustainable development goals in general, and education in particular.

The potential for involvement of civil society institutions in implementation of sustainable development measures has not been realized.

The analysis shows that despite the progressive inclusion of sustainable development targets in strategic planning documents, there is still no direct alignment of indicators of national and federal projects with sustainable development goals within the sphere of influence of higher education system.

\section{Conclusion}

It should be noted that the dynamic development of social relations does not allow sustainable development to be seen as a formalised plan with clear and constant indicators. At the present time there is a search for effective models of economy, which are able to fully ensure the implementation of the principle of social justice in the conditions of environmentally sound development.

The existence of controversial issues in the sphere of interpretation of the concept «sustainable development», as well as its indicators [12] allows us to state the great potential of research in this sphere. It can be noted with confidence that the final conceptualization of a set of indicators of sustainable development goals has not occurred both globally and nationally.

The data presented in the paper shows that there are problems in Russia in implementing the fourth Sustainable Development Goal regarding education in general and higher education in particular.

It is worth mentioning that the concept of sustainable development originated as an ecological concept, but it has evolved retrospectively to include economic contexts and eventually to become a comprehensive ideology of harmonised development of humanity. Along with the evolution of the concept, the place and role of higher education in achieving sustainable development has changed. At present, the world is actively searching for a new model of higher education, capable of harmonizing the environmental, social and economic aspects $[13,14]$. The analysis of one of the many indicators of the development of higher education for sustainable development reveals the existence of regional differentiation of education accessibility.

The deployment of higher education for sustainable development requires a constant updating of its model to reflect the changing context. The 17-21 age cohort is expected to grow by $15 \%$ in 2024 and $45 \%$ by 2034 , putting inequalities and social tensions in tertiary education on the agenda for the coming years. The role played by the higher education system in the sustainable development paradigm obliges the state and society to consolidate efforts to preventively address regional disparities.

\section{References}

1. K. Vladimirova, D. Le Blanc, Sust. Dev., 24, 254 (2016)

2. E. González García, E. Colomo Magaña, A. Cívico Ariza, Sustainability, 12(15) (2020)

3. M. Chankseliani, T. McCowan, Higher education and the sustainable development goals, Higher Education (2020)

4. $\quad \mathrm{M}^{\mathrm{a}}$ del Carmen Olmos-Gómez, L. Isabel Estrada-Vidal, F. Ruiz-Garzón, R. LópezCordero, L. Mohamed-Mohand, Sustainability, 11(24) (2019) 
5. P. Nijkamp, P. Laschuit, F. Soeteman, Sustainable development in a regional system (1991)

6. Report of the World Commission on Environment and Development: Our Common Future, https://sustainabledevelopment.un.org/

7. E. Prieto-Jiménez, L. López-Catalán, B. López-Catalán, G. DomínguezFernández, Sustainability, 13(4) (2021)

8. UNESCO Roadmap for Implementing the Global Action Programme on Education for Sustainable Development, https://unesdoc.unesco.org

9. Federal State Statistics Service, https://rosstat.gov.ru/

10. Statistical information in the sphere of research, development, and higher education. Higher education, Ministry of Science and Higher Education of the Russian Federation, https://minobrnauki.gov.ru/

11. Bulletin of the Accounts Chamber of the Russian Federation, 2020, № 6. Sustainable Development Goals, https://ach.gov.ru/

12. R. Valderrama-Hernández, F. Sánchez-Carracedo, L. Alcántara Rubio, D. LimónDomínguez, Sustainability, 12(1) (2019)

13. S. Stein, Educational Studies, 55, 667 (2019)

14. Ruiz-Mallén, M. Heras, Sustainability, 12(4), 1290 (2020 